\title{
Macroenvironmental Forces, Marketing Strategy and Business Performance: A Futures Research Approach
}

\author{
Robert F. Lusch \\ University of Oklahoma \\ Gene R. Laczniak \\ Marquette University
}

\begin{abstract}
A method of futures research is used to empirically test a structure-conduct-performance (SCP) model in a marketing setting. It is proposed that within the macroenvironment there exist, varying levels of resource constraints and structural fluctuations which are positively correlated. Increased resource constraints and structural fluctuations, which are characteristics of a turbulent environment, are expected to increase the competititive intensity in an industry. This higher level of competitive intensity is hypothesized to result in increased use of nonprice marketing strategies. Nonprice marketing strategies are also expected to increase business performance because of the contingency relationship between conduct (strategy) and performance. The possible role of "blind" luck or stochastic processes in determining success is also discussed.
\end{abstract}

\section{INTRODUCTION}

The structure-conduct-performance (SCP) paradigm which is well developed in the industrial economics literature (Caves 1964, Weiss 1971, Vernon 1972, Scherer 1980) has received little explicit attention in marketing. This is unfortunate because marketers often deal with constructs which can be derived from the abstract SCP paradigm. For example,

Journal of the Academy of Marketing Science

Volume 17, Number 4, pages 283.295.

Copyright 01989 by Academy of Marketing Sdence.

All rights of reproduction in any form reserved.

ISSN 0092-0703. the external environments which marketers address including the competitive environment can characterize the "structure" of the environment a firm is constrained by; the marketing mix decisions are typical of the firm "conduct" construct; and a orientation toward customer satisfaction and profitability are representative of the "performance" construct. ${ }^{1}$

The purpose of this article is to use the SCP paradigm to derive constructs that can be fashioned together in a causal nexus to explain marketing phenomena. In this regard we posit that resource constraints and structural fluctuations impact competitive intensity (these are structure constructs), which in turn influence nonprice competitive strategy (this is a conduct construct), which is expected to influence business performance (this is a performance construct). We also offer an empirical test of these causal associations. In an attempt to explore a new survey research orientation in marketing this theory will be vitalized using an approach drawn from " $\mathrm{fu}$ tures reseanch" methods. If our attempts at deriving systematic propositions from the abstract SCP paradigm are fruitful, then support will be obtained for future attempts to use the SCP paradigm in scholarly research in marketing.

In the pages that follow, a theory which fleshes out some of the critical components of the SCP model is derived. Hypotheses based on this theory are then postulated. A sample of high ranking executives are asked to forecast the future business environment and to speculate about the likely strategy which is evoked by their predictions. This futures forecast becomes the basis for a Lisrel analysis which tests the proposed hypotheses. Finally, implications for the structure-conduct-performance orientation are discussed and related to marketing strategy. 


\section{THEORY DEVELOPMENT}

The theory to be developed relates to the SCP model portrayed in Exhibit 1. The model has three theoretical constructs: structure, conduct, and performance. ${ }^{2}$ From the theoretical construct of structure is derived three constructs at a lower level of abstraction and these are resource constraints, structural fluctuations, and competitive intensity. In Exhibit 1 the theoretical constructs are linked to derived constructs by straight lines without arrows. Derived from the theoretical construct of conduct is nonprice competitive strategy and derived from the performance construct is business performance.

Hypotheses will be developed in the following sections that link the derived constructs together. When the derived constructs are linked by a straight line with an arrow we are hypothesizing a causal direction; on the other hand when two derived constructs are linked by a curved line with an arrow at both ends we are predicting a correlated relationship but no causal direction. Superimposed on these lines are numbers which represent the hypothesis number to be discussed in the theory development section that follows. On preview of Exhibit 1 we note that Hypothesis 1 posits that structural fluctuations and resource constraints are positively related.
Hypothesis 2 argues that resource constraints influence competitive intensity and Hypothesis 3 suggests that structural fluctuations influence competitive intensity. In Hypothesis 4 we predict that competitive intensity influences nonprice competitive strategies. Finally, Hypothesis 5 predicts nonprice competitive strategy will influence business performance.

The model in Exhibit 1, which will be given theoretical support and empirically tested, is simple but does represent a preliminary attempt to use the SCP paradigm in marketing. More detailed and complex models are left to future research efforts.

\section{Paradigm Component \#1: Structure}

\section{Definition}

As a sociological construct, structure may be defined as the arrangement of parts or the pattern of organization in a social system. Thus, structure involves the notion of systems. Glasser and Halliday (1980, p. 918) state that "at its core, systems theory is concemed with the ways in which a given set of elements is related. ..." Consequently, this article will rely heavily on concepts from systems theory as well as the fundamental attributes of systems.

\section{EXHIBIT 1}

\section{SCP Model}

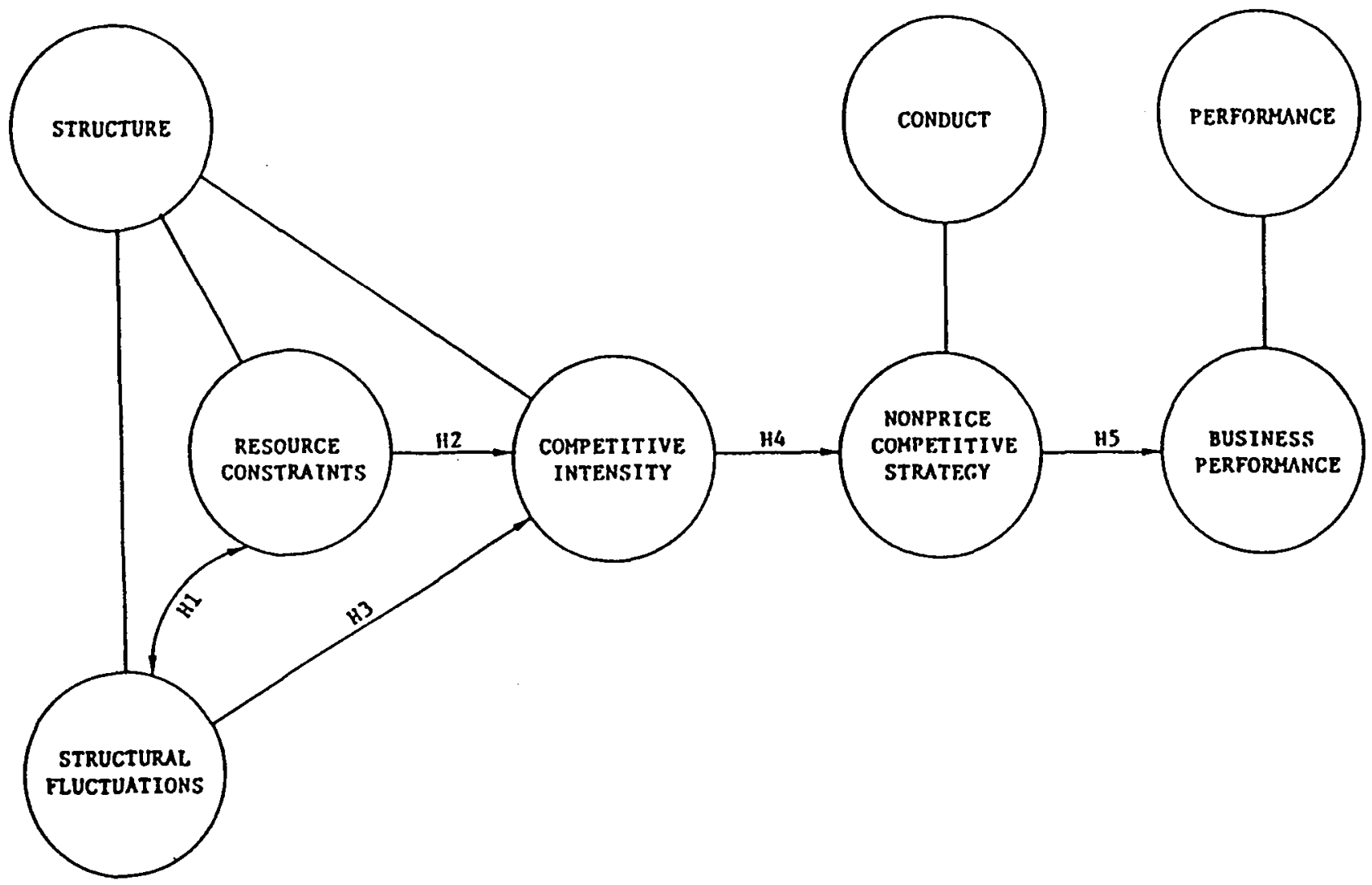




\section{Open/Closed Systems}

A closed system does not import energy; an open system does import energy (Dowling 1983). According to the second law of thermodynamics, a closed system experiences increasing entropy (that is, the loss of potential) over time. On the other hand, open systems because they can import energy, are able to avoid entropic processes. A closed system typically has a simpler structure because only the parts within the system need to be related to the whole (Emery and Trist 1965 , p. 21). In contrast, an open system requires not only that processes within a system be structured but also that the relations between system and environment be established along with the relationship between parts of the environment (Emery and Trist 1965, p. 22; Dowling 1983, p. 24).

\section{Resource Constraints}

Energy is the ability to do work and all systems require energy. At a high level of abstraction any resource is a form of energy. Oil is energy, water is energy, human labor is energy, knowledge or "know-how" is energy. Zimmerman (1951) suggests that the critical systemic resource is information (or know-how) because it is used to transform "neutral stuff" into resources. For example, oil was neutral matter until we knew what to do with it. Open systems although they have the ability to import energy, will at times experience resource or energy constraints. These constraints will influence the functioning of the system. Our first derived construct deals with these resource constraints which we define as the extent to which the system is unable to obtain all the resources necessary for suitable functioning.

\section{Structural Fluctuations}

When systems are unable to obtain the necessary resources, they begin to break apart; entropy and eventually chaos sets in. This increase in entropy (that is, the deterioration of existing resources) results in a disequilibrium which causes structural fluctuations to materialize (Monieson 1981).

In the management literature, the close relationship between resource constraints and structural fluctuations was most ably pointed out by Emery and Trist (1965) within their articulation of the concept of the turbulent environment. Basically, environments were turbulent when interconnected organizations (for example, competitors) were concurrently seeking limited resources. When sufficient resources were not attracted, one outcome was structural fluctuation. Terreberry (1968) extended these insights when she contended that most organizational climates were becoming more turbulent and uncertain.

Reidenbach and Oliva (1982) also underscore the importance of studying structural fluctuations in marketing systems by relating these fluctuations to morphogenesis. "The problem of morphogenesis deals with the nature of structural changes at various system levels. The essence of morphogenesis dictates that macromarketing models must be capable of explaining and predicting the structural dynamism inherent within social systems" (Reidenbach and Oliva 1982, p. 243). Importantly, the structural dynamism stimulated by structural fluctuations is the source of new order (Prigogine 1978). Consequently, our second derived construct deals with structural fluctuations and is defined as the oscillations in structure that occur when the system is in disequilibrium.

Structural fluctuations and resource constraints should be positively associated because as the system experiences resource constraints the existing structures will begin to break apart (that is, develop entropy). Eventually this will allow a new order or structure to emerge. What basically occurs is that resource constraints cause a state of nonequilibrium which triggers increased instability and accompanying structural fluctuations (Nicolis and Prigogine 1977). This is known to be the case for open systems that are chemical and biological in nature. The intriguing question is, does this same process occur in open systems that are economic or sociological in origin? Nicolis and Prigogine (1977) believe so, we also believe the answer is yes. As Henderson (1983) recently wrote concerning marketing strategy, "there is no reason to think of business competitive systems as being different in any fundamental way from other biological competition. ... The basic principles of competition are as universal as the laws of chemistry and physics are universal." (Henderson, 1983, p. 8).

\section{Social versus Natural Systems}

Our belief and assumption is that social and natural systems both undergo the same abstract systemic processes. Long ago Desaubliaux (1919) in the reports of the Meetings of the Society of the Mineral Industry ${ }^{3}$ persuasively discussed the biological origins of the administrative function and argued that physiological man is indeed the same as the social man. Others have observed that biological, economic, and social systems are open systems (for example, Adams 1978). Furthermore, Boulding $(1956,1981)$ discusses how biological and economic or social systems are similar in terms of evolutionary and systems concepts. Also Kangun (1981) illustrates how the entropy law is applicable to economic and marketing processes. Measures of entropy have appeared in research in accounting (Adel-Khalik 1974), economics (Horowitz and Horowitz 1968), finance (Cozzalino and Zahner 1973), and marketing (Herniter 1973). Ayres and Nair (1984) state that "because goods and services incorporate matter and energy, the physical sciences are clearly relevant to economics" ( $p$. 62). Finally, Reidenbach and Oliva (1983) use the laws of thermodynamics (which deal with entropy) to provide a theoretical framework for examining marketing's macro systemic effects.

The principles of thermodynamics and equilibrium statistical mechanics cannot explain the formation of new structures and the increasing complexity of these structures. In other words, these laws cannot explain the type of order that emerges out of chaos or what is commonly referred to as "the order through disorder" phenomenon (Prigogine and Stengers 1984). What is needed to further explanation in a marketing context, is the recognition that economic systems are open systems that are often far from equilibrium. Such systems are able to maintain and reproduce themselves because of a continuous exchange of energy and matter with the surroundings (Prigogine, Nicolis, and Babloyantz 1972a, pp. 23-24). One framework developed by Prigogine describes a thermodynamic model of nonequilibrium systems which shows that nonequilibrium may become a source of order, 
essentially fluctuations in the structure of a system are stabilized by exchanges with the outside world and a new order thus emerges. ${ }^{4}$ However, the emergence of this new order is essentially stochastic in nature. Although his examples are in chemistry, it has been argued that the theory has applicability to all nonequilibrium open systems (Dowling 1983; Maruyama 1978).

\section{Resource Constraints and Structural Fluctuations}

The preceding discussion argues that economic and social systems are open systems where resource constraints are triggered far from equilibrium which then catalyze structural fluctuations. However, it is difficult for us to hypothesize the exact causal direction between resource constraints and structural fluctuations. This is because increased structural fluctuations may result in less resource efficiency and thus increase resource constraints. At the same time, resource constraints may cause increased structural fluctuations as a new system order or structure is sought. We agree with marketers Monieson and Shapiro (1980) who point out that functionalists believe scarcities (resource constraints) cause social change (structural fluctuations). For example, the shortage of oil in the early 1970's (a macroenvironmental resource constraint) caused a shakeout of retail service stations that had provided the consumer with gasoline for their automobiles. In order to increase their probability of survival, many full service stations became "self service" operations. This coping mechanism represented a structural adjustment. The structural fluctuation created a shortage in automotive services (another resource constraint) which provided the opportunity for other retailers (specialists, such as tire and muffler dealers) to expand their automotive services (a new structural adjustment) to fill the void. Thus, using the arguments of the above discussion, the first hypothesis that we suggest is:

H1: Structural fluctuations and resource constraints are positively correlated; as one rises so does the other.

\section{Competitive Intensity}

Structural fluctuations and resource constraints are part of the turbulent macroenvironment. However the business firm - our strategic unit of concern-is most directly buffeted by the competitive environment. The competitive environment consists of the rivalrous activity of independent organizations attempting to secure mutually desired resources of limited supply (adapted from Porter 1980). This brings to the fore a third derived construct - competitive intensity which we define as the strength of rivalrous activity in the competitive environment.

Both structural fluctuations and resource constraints can be expected to have an impact on competitive intensity. When existing structures begin to dissipate their energy then resources that were previously bonded to those structures may decouple and have improved mobility. When resources can move more freely, both entry and exit barriers are lower (Porter 1980). Typically, this situation will attract a greater number of competitors than previously existed in the market. However, not all key resources can be accommodated by reduced barriers to entry. For example, managerial talent with appropriate experience and patent protected production capability (for instance) cannot easily be increased. Thus, as key resources become more scarce, there will be more rivalrous activity since the same number or more players are chasing a finite resource supply. The same holds true when the absolute level of available resources declines, but the number of players who wish to participate stays about the same. For example, the extreme profit pressures upon the steel industry during the past decade reduced production capacity in certain world markets (such as the U.S.) and resulted in a surplus of experienced executive talent (some with personal capital to invest) who were looking for employment. This and other factors led to the construction of modern "mini mills" to produce certain specialty steels which further intensified sectors of this competitive environment. This discussion suggests two hypotheses:

H2: Increased resource constraints are associated with higher competitive intensity.

H3: Increased structural fluctuations are associated with higher competitive intensity.

It should be noted again that if one views structural fluctuations and resource constraints as macroenvironmental factors associated with a turbulent environment then the work of Metcalfe (1974) also supports these two hypotheses. Metcalfe states, "Crises brought about by the inability to cope with environmental change force organizations to compete and conflict in ways which systematically and unavoidably frustrate each others' policies" (p. 653). The work of Glasser and Halliday (1980) would also support our hypotheses. This pair of authors suggest that "environmental pressures disturb the organization's stability or equilibrium over time" (Glasser and Halliday 1980, p. 920). Thus, this increased environmental turbulence would be expected to elicit increased competitive intensity.

\section{Paradigm Component \#2: Conduct}

As a theoretical construct, conduct is defined as the pattern of behavior that a business firm follows in adapting and adjusting to the environment (adapted from Preston 1977, p. 34). A business firm is confronted by an environment that continuously changes; but the firm cannot react to every change. All of these changes are not relevant to a particular firm. If it reacted to everything, the organization would be so flexible as to lessen its survival potential (Cook 1980). This is because organizational change creates a certain degree of organizational anxiety or tension. Thus, top management often wishes to minimize such tension (Watson 1972). Rather it would appear more likely that a firm responds only to those forces that increase competitive intensity (Henderson 1983). As Henderson put it, "The strength of any marketing strategy, depends on the competitive analysis upon which it is based" (p. 7). This would suggest that unless a macroenvironmental force affects an industry and results in a change in competitive intensity, a firm's conduct will not be substantially altered.

Since the purpose of this research was to provide only a 
preliminary assessment of the structure-conduct-performance paradigm, we decided to focus on one (fairly comprehensive) element of the firm's conduct. However, we wanted it to be a type of conduct that represented a broad response to competitive intensity. Since competition in the U:S. is largely characterized by monopolistic and oligopolistic competition, the most typical responses to increased competitive intensity involve increased emphasis on nonprice marketing strategies. These consist of strategies that focus on product, promotion, and distribution elements of the marketing mix. Nonprice marketing strategies have grown in popularity because many price changes can be quickly duplicated while nonprice strategies can be used to differentiate the firm's offering and actually give it more lasting appeal (Shaw 1912; Lockley 1964; Udell 1972). This approach has been recognized in general economic theory since Chamberlain (1958) articulated his vision of product differentiation. In short, nonprice strategies allow the furm to alter the shape of its demand curve rather than simply moving along the same curve. Thus our fourth hypothesis is:

H4: Increased competitive intensity will result in more emphasis on nonprice marketing strategies.

\section{Paradigm Component \#3: Performance}

The final linkage in the SCP paradigm is performance. Performance as a theoretical construct is defined as the accomplishments or outcomes of an entity. The derived construct is business performance which we define as the total economic results of the activities undertaken by an organization.

It is not easy to speculate about how conduct in the form of nonprice strategies may influence business performance. One could expect that a rational economic person operating as a manager wouldn't engage in nonprice strategy unless it would increase organizational performance. Of course, this assumes that managers have perfect information or make decisions under certainty. This is seldom (if ever) the case because the manager faces uncertainty about the slopes of demand and supply curves and about the host of environmental forces that influence their shape (Alchian 1950, p. 212). Lazer and Kelley (1962) state that most marketing systems are open systems in which chance and probability play a key role and for which planning is difficult.

It can be argued that many businesses in the U.S. operate in what Emery and Trist (1965) and Dowling (1983) refer to as turbulent environments. These are environments in which the rate of change in the environment is high and the organization has a high level of interdependency with environmental elements. In a turbulent environment the level of uncertainty is high. It can also be argued that firms would not require a "risk" premium on investment projects if the world or environments they operated in were certain. If capital costs a firm 12 percent and the firm targets new investment projects to retum 25 percent, then the firm likely perceives a high degree of environmental uncertainty. Using a mone pragmatic line of reasoning, perhaps what makes business so exciting and captivating to a continuous flow of new "players" is its inherent riskiness and uncertainty. In the language of the street, "business is a game of high stakes poker."

The inherent uncertainty in the environment does not prevent managers from attempting to make very thoughtful decisions about strategy that they see fitting the environment that will unfold in the future. Clearly, managers - the players of the business game-perceive that their strategy adjustments should finally lead to improved organizational performance. This is the essense of contingency theory which posits that managers adjust their controllable strategies to the environment in order to enhance financial outcomes (Hofer and Schendel 1978; Pfeffer and Salancik, 1978). In marketing, this is also the conventional wisdom. As Day (1984) has noted, the "ultimate test" of the effectiveness of a strategy is its impact upon outcomes including sales growth, profitability, and economic value generation. Similarly, Aaker (1984) in his commentaries concerning the evaluation of objectives and strategy has observed that "the ultimate bottom line test" of strategy outcomes is seen in its influence upon profitability. In fact, one of the most famous ongoing data bases upon which marketing academics have based their strategy insights is called PIMS - an acronym for profit impact of marketing strategies. The very name suggests that there is necessarily a relationship between strategy and profit (Ramanujum and Venkatramon 1984). Thus, as the environment becomes more competitive and management turns to increasing use of nonprice competitive strategies, we would expect that managers also perceive that their strategy adjustments will lead to increased business performance. Stated formally:

H5: Increased emphasis on nonprice marketing strategies is related to an expectation of higher business performance.

\section{RESEARCH METHOD}

\section{Shortcomings of Traditional Methods}

The traditional methods of collecting data to test the structure-conduct-performance paradigm are plagued with problems. For example, to test the proposed hypotheses many approaches are possible. Perhaps the ideal approach would be to collect (a) objective historical data on resource constraints, structural fluctuations, and competitive intensity; (b) information concerning the firm's use of nonprice strategies; as well as (c) measures of organizational performance. Except for the latter measure this task is close to impossible. In truth, even the measurement of organizational performance would be difficult because of the confounding factors of mergers, tax laws unique to specific industries, differing accounting methods (that is, LIFO versus FIFO inventory valuation), and problems of historical versus current value accounting. In regard to the structure-conduct-performance paradigm of industrial organization economics, Carman $(1977$, p. 150) has stated that ..." there are serious measurement problems which are sufficient to discourage all but the strongest scholars."

Of extreme difficulty is the measurement of firm conduct. 
Scherer states that firm conduct has been difficult to analyze quantitatively but at least its consequences are observable in terms of performance indicators (Scherer 1980, p. 268). He notes, "The typical structure-performance analysis excludes explicit conduct variables, partly because they are so hard to measure and partly because it is believed that performance can be 'explained' statistically merely on the basis of variables reflecting market structure and fundamental supply and demand conditions"' (Scherer 1980, p. 276).

\section{Executive Perceptions versus Objective Dala}

One method for partially overcoming the preceding problems is to obtain executive perceptions of the major constructs in the hypotheses. That is, executive perceptions could be obtained of indicators of resource constraints, structural fluctuations, competitive intensity, nonprice marketing strategies, and organizational performance. Robey (1982) contends that the weight of research supports the relationship between executive perceptions of the strategic situation and subsequent organizational actions. This approach has the pragmatic advantage of being doable. In marketing, the utilization of a sample of executive perceptions is common in order to set the stage for a conceptual or empirical treatment of an emerging issue (Montgomery and Weinberg 1979; Webster 1981; Hunt and Chonko 1984). The idea is to integrate multiple and diverse executive opinions in a manner which indicates what the emerging trends might be concerning a particular marketing development.

Executive perceptions could be obtained about the past, present, or future. The major problem in gathering executive perceptions of the past is that today's executives were likely to not have been in senior management positions during the time period for which they would be questioned. Essentially, they would not be reliable, key-informants of the organization's past behavior. On the other hand, the obstacle in gathering perceptions of the present is that the responding executives might rationalize their present decisions and behavior. The last alternative is to gather perceptions of the future, this was the approach selected.

\section{Futures Research Methodology}

In recent years there has been a growing interest in the application of futures research techniques to business forecasting and planning. Fawles (1978) among others, provides an anthology of the purposes and methods of futures research. In marketing planning, two techniques have been especially prominent: the Delphi and scenarios. For example, Pearce and Robinson (1983) discuss the critical relationship between the Delphi and environmental scanning as it is evolving in the market analysis of many organizations. Linnemann and Klein (1985) have documented the growing use of scenarios as an aid to strategic decision-making. In effect, we implemented a hybrid approach to futures research by utilizing elements of both the Delphi and the scenario technique. Our sample group of experts-high level Fortune 500 executives-is the fundamental feature of the Delphi approach. A series of statements about the possible importance of various strategies constituted a disaggregated scenario technique. As Edmundo (1982; p. 45) has noted: ". . . micro and macro interactions are the essense of which business strategy and policy is made ... A plausible approach to dealing with these complex interactions is to pursue futures studies as a mode of examining the probabilities of alternative future scenarios and then checking which events of the scenarios unfold." In accordance with the above, we recorded the perceptions that executives hold of the environment of business in 1995 as well as the emphasis they thought would be placed on nonprice marketing strategies. In addition, the executives were asked to state their expectations of organizational performance in 1995 in light of their other predictions. Ten years in the future is of a sufficiently long time horizon that responses should not be tainted by current prejudices, biases, or vested interests. Most executives ten years from now will be in a different position in the organization or retired, or employed elsewhere and thus their responses about the organization in 1995 should be unfettered by self-serving concerns. We also believe that theory testing can occur via collecting data about perceptions of the future (Lusch and Laczniak 1979) because executives have rudimentary theories of the "if A then B" type which direct and guide their behavior. Zaltman, LeMasters, and Heffring (1982) refer to these as "theory in use." Wilson and Ghingold (1980 p. 236) suggest that the theory-in-use "approach to theory building represents a more inductive, inferential process and is based on a simple notion that individual practitioners develop personal rules of action which can be codified into a theory." The futures research methodology developed in this article is a covert way of identifying these rules of action. In brief, if we ask executives about the future then we should be able to determine what they will do (action $B$ ) if confronted with situation A. And these uncovered "if A then B" relations would likely extend to the decision nules which guide their current behavior.

\section{Surveyed Population}

The population we surveyed consisted of Fortune 500 executives. The questionnaire was eight pages and consisted of a large battery of questions about the business environment, the firm's conduct, and expected business performance in 1995. Only the subset of these questions that relate to the constructs in the hypotheses developed, are used in the research reported in this article. Questionnaires were sent by mail and a total of 103 usable responses were obtained. All of the respondents were high level executives-typically VP's of Marketing or Planning. Clearly, all qualified as organizational elites who were keenly knowledgeable of organizational strategy. A second wave of the questionnaires was not mailed because it was our experience that large organizations typically have policies or strong opinions about responding to unsolicited questionnaires; if they don't respond the first time they are unlikely to respond to further prodding.

\section{Statistical Method}

Structural equations with unobservable or latent constructs were used to test the hypotheses using the LISREL program 
. ithe assessment of both the measurement of conif the structural relationship between constructs. The itof matrix between indicators of the constructs will gas the input in the LISREL program.

\section{arisement}

stifit 2 provides information on how the structure conis were measured and their associated scale statistics. initice constraints was measured by the summated score thems that reflected the likelihood that resource consictits would substantially occur by 1995 . The likelihood s. $x$ itiad six points: 0 percent, 20 percent, 40 percent, 60 ficint 80 percent, 100 percent. The items included in this inction were developed by reviewing the literature concemint the future U.S. and global environment as reported by , petiodicals such as the Futurist, the Trend Analysis Program Sinthe American Council of Life Insurance, the Naisbett group; and the Center for Futures Research at the University of Southern California.

The final pool of items represented a judgment call by the authors, and as shown in Exhibit 2, included such resource dimensions as education, petroleum, and food availability. This scale had a standardized coefficient alpha of .77 which suggested it had adequate reliability for basic research (Nun- nally 1967). Structural fluctuations was measured by the summated score on eleven items that reflected the likelihood that systemic fluctuations would substantially occur by 1995 . The items included in this measure were developed in a manner analogous to the resource constraints construct. The final pool of these items, also enumerated in Exhibit 2, includes such structural fluctuations as inflation, unemployment, consumerism, technological backlash, and so forth. The standardized coefficient alpha for this scale was .79; which was an acceptable indicator of reliability.

One of the fundamental differences between the items listed under resource constraints and structural fluctuations is that the former tend to represent inputs whereas the latter are generally reactions of the system. While there may be some debate among reasonable persons about the placement of some of the items (for example, unemployment), we should recall that both factors are dimensions of the turbulent environment and that they are postulated to act in tandem to influence competitive intensity and strategy. Finally, competitive intensity was measured by three items, each scored on a five-point scale ranging from strongly disagree to strongly agree. The measures of competitive intensity included an item reflecting input (increased spending on marketing), output (maintenance of market share) as well as a global measure. Respondents were also asked to state their degree of agreement or disagreement about the state of competition

\section{EXHIBIT 2}

Structure Scales

\begin{tabular}{|c|c|c|}
\hline Scale and Items & $\begin{array}{l}\text { Item-Total } \\
\text { Correlation }\end{array}$ & $\begin{array}{c}\text { Standardized } \\
\text { Alpha }\end{array}$ \\
\hline $\begin{array}{l}\text { Resource Constraints }\left(X_{1}\right) \\
\text { An infrastructure crisis (affecting roads, schools, public services) will be pervasive in many cities. } \\
\text { The quality of public education at the primary, secondary, and tertiary levels will be a major concem } \\
\text { throughout the } 1990 \text { 's. } \\
\text { Eighty percent of married households will be two-income households. } \\
\text { Increased global pollution requiring substantial intemational cooperation. } \\
\text { Worddwide struggle over rights to mine the oceans. } \\
\text { Worldwide shortages of food occur. } \\
\text { Worldwide shortages of oil occur. } \\
\text { A significant water shortage develops in at least five states in the U.S. } \\
\text { The oceans will be a frontier for major scientific developments. } \\
\text { Space will be a frontier for major scientific developments. }\end{array}$ & $\begin{array}{l}.27 \\
.29 \\
.40 \\
.57 \\
.54 \\
.36 \\
.37 \\
.52 \\
.58 \\
.50\end{array}$ & .77 \\
\hline $\begin{array}{l}\text { Structural F/uclations }\left(X_{2}\right) \\
\text { There will be a prevailing climate of social and ethical problems caused by advancing technology. } \\
\text { A consumer backlash against HI-TECH Developments such as biogenetics and electronics funds transfer. } \\
\text { The U.S. adopts an industrial policy whereby the federal govemment assists key industries } \\
\text { to be world-competitive. }\end{array}$ & $\begin{array}{l}.45 \\
.46 \\
.39\end{array}$ & .79 \\
\hline $\begin{array}{l}\text { There will be a movement toward the use of more out side directors that represent stockholder groups } \\
\text { alch as labor, consurners, the community, etc. } \\
\text { The U.S. enacts measures which severely restrict foreign invertment in the U.S. } \\
\text { A revival of consumerism to } 1960 \text { 's levels of intensity will occur. } \\
\text { Unemployment exceeding } 10 \text { percent in most developed countries. } \\
\text { There will be major effors to develop international codes of conduct for the operation of multinationals. } \\
\text { lnflation exceeding } 15 \text { percent in most developed countries. } \\
\text { Widespread political and financial instability in less-developed countries causing worldwide economic instability. } \\
\text { A climate of protectionism characierized by periodic intemational trade wars and the formation of regional } \\
\text { alliances to increase leverage in world trade. }\end{array}$ & $\begin{array}{l}.43 \\
.39 \\
.30 \\
.46 \\
.47 \\
.49 \\
.53 \\
.55\end{array}$ & \\
\hline $\begin{array}{l}\text { Competitive Intensity } \\
\text { Firms will be spending more of each sales dollar in marketing due to increased competition. }\left(Y_{1}\right) \\
\text { Firms in our industry will be aggressively fighting to hold onto their share of the market. }\left(Y_{2}\right) \\
\text { Competition will be more intense. }\left(Y_{3}\right)\end{array}$ & $\begin{array}{l}.53 \\
.49 \\
.55\end{array}$ & .71 \\
\hline
\end{tabular}




\section{EXHIBIT 3}

\section{Conduct And Performance Measurement}

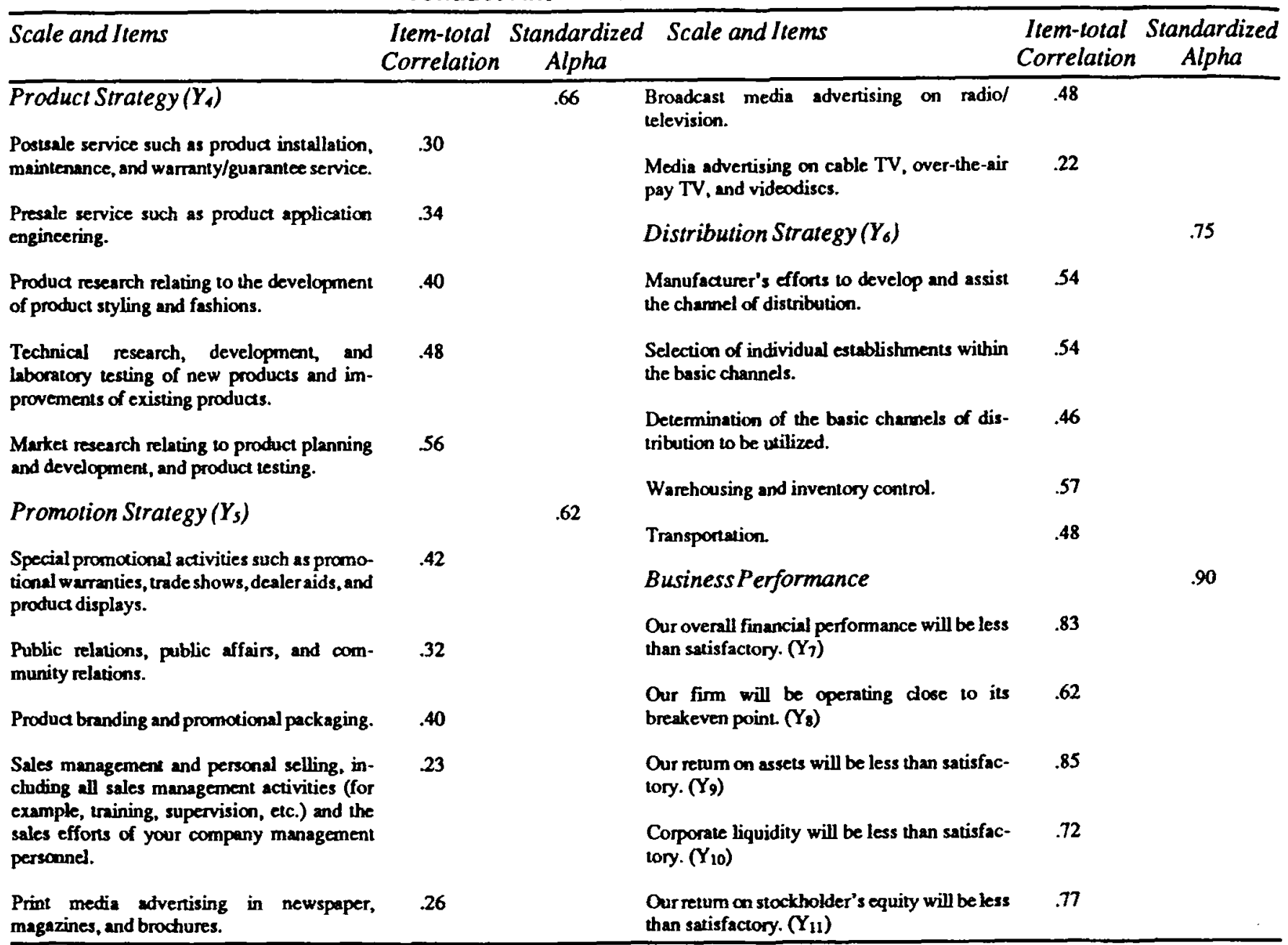

in 1995. The standardized coefficient for this scale was .71 and evidenced acceptable reliability for the competitive intensity construct.

Exhibit 3 provides information on the measurement of the conduct and performance constructs. Nonprice marketing strategy was indicated by three scales. The items from these three scales came from research by Udell (1972), Lusch, Laczniak, and Udell (1976) and Robicheaux (1976). The product strategy scale consisted of five items scored on a five-point scale that ranged from greatly decreased importance to greatly increased importance. The executives were told to indicate the degree to which they believed that the respective elements of marketing strategy would increase or decrease in importance by 1995 . The product strategy scale had a coefficient alpha of .66 . The promotion strategy scale was scored on the same five-point rating and was comprised of seven items. The scale had a coefficient of .62 . The third scale was distribution strategy and it had a coefficient of .75 . It was scored in a fashion similar to the previous two scales and had five items.

Business performance was measured with five items (see
Exhibit 3) reflecting perceptions of return on assets, liquidity, breakeven points, return on equity, and a global measure of financial performance in 1995. Again, the notion is consistent with the position of Enis (1982) that financial performance is usually an indicator of how well an organization is serving consumers in its marketplace. Executives responded to the above mentioned items on a four-point rating scale that went from strongly disagree to agree. The rating scale was reverse scored so high numbers would reflect high performance. The coefficient alpha for the summated scale of these five items was .90. Thus, in essense 103 high-level executives were being asked to comment on fundamental dimensions of the external business environment in 1995. Based on the vision which they project, they were asked about how such an environment might affect nonprice competitive strategies and what the outcome on organizational performance might be. In effect, the unit of analysis in this study was to evaluate the determinants and outcomes of strategy at the corporate level. Recent writings have emphasized the importance of evaluating strategy at the corporate level (Wind and Robertson 1983) but empirical efforts in this realm have been in short supply 


\section{Lisrel Model of Hypothesized SCP Model}

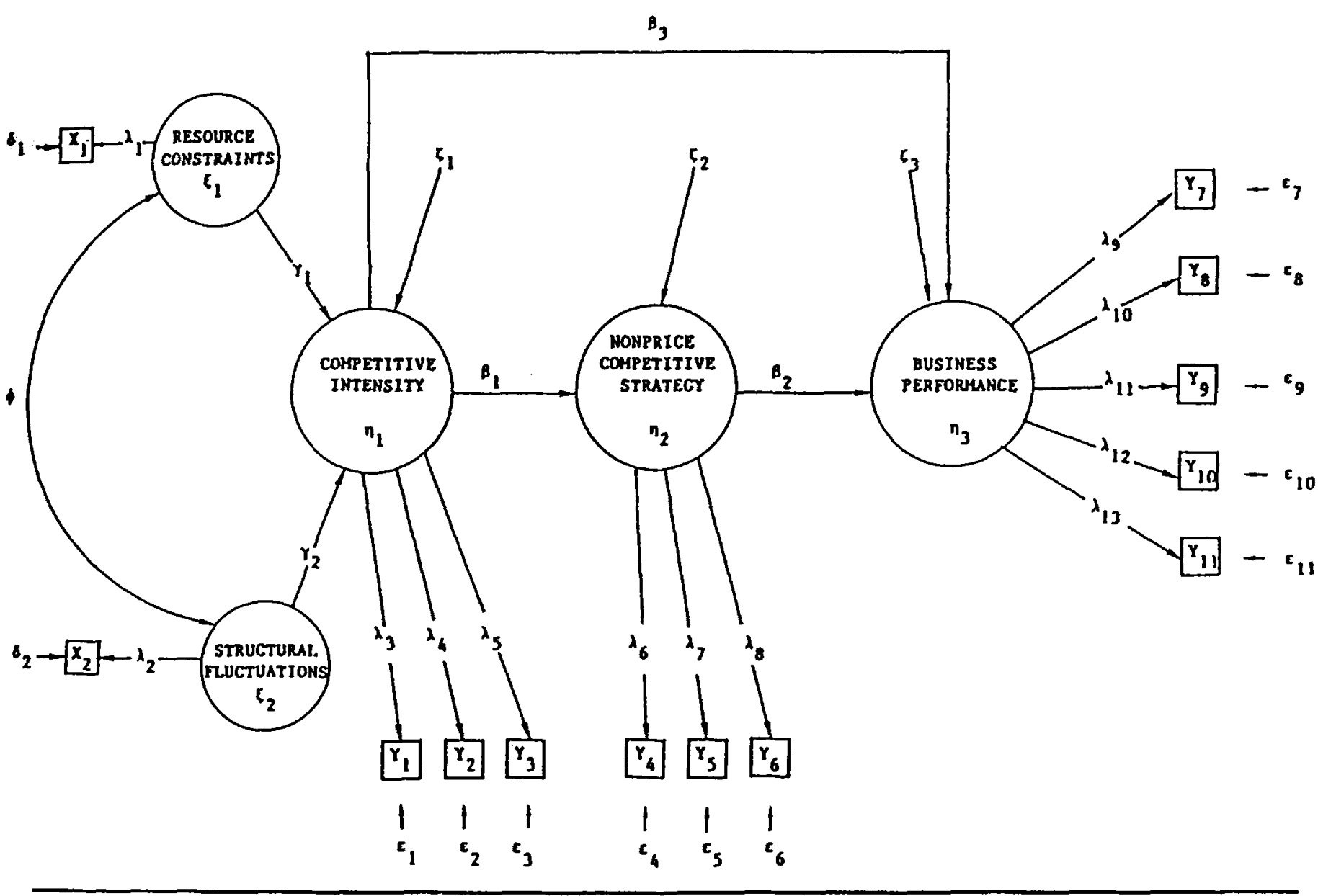

with a few notable exceptions (Hutt, Ireland, and Stadter, 1982).

\section{RESULTS}

The Lisrel model to be tested is presented in Exhibit 4. This model has six structural parameters and five of these refer to the five hypotheses: $\mathrm{Hl}$ suggests that phi should be postive; $\mathrm{H} 2$ suggests that gamma- 1 should be positive; $\mathrm{H} 3$ hypothesizes a positive value for gamma-2; $\mathrm{H} 4$ suggests that beta- 1 should be positive; and $\mathrm{H} 5$ predicts that beta- 2 will be positive. The sixth structural parameter is beta-3 which shows a direct structural linkage between competitive intensity and business performance. We did not formally hypothesize this link but it is reasonable to expect that competitive intensity has a direct effect on business performance as well as a possible indirect effect via its influence on nonprice marketing strategy. The conventional wisdom of economics would suggest that beta- 3 would be negative, increased competitive intensity is associated with lower business performance (Porter 1980).
The parameter estimates for the Lisrel Model are presented in Exhibit 5.

The first hypothesis is strongly supported since the phi parameter is .422 and statistically significant beyond the .01 level. Resource constraints and structural fluctuations are positively associated. This suggests that a systems interpretation of business environmental turbulence may be on target.

The second hypothesis also received strong support since the gamma-1 parameter was .346 and significant beyond the .01 level. Increased resource constraints are associated with higher levels of competitive intensity. This is in consonance with the earlier articulated view that economic competition may be regulated by the same forces as biological competition.

The third hypothesis cannot be supported since gamma-2 is not statiscally significant. Increased structural fluctuations are not associated with higher levels of competitive intensity. This outcome was a surprise. It seems to suggest that certain systemic dynamics-for instance, inflation, consumerism, and protectionism-can be increasing without directly significantly altering the competitive climate.

Strong support is obtained for the fourth hypothesis since 


\section{EXHIBIT 5}

Parameter Estimates for LIsrel Model

\begin{tabular}{|c|c|c|c|}
\hline Parameter & $\begin{array}{c}\text { Maximum } \\
\text { Likelihood } \\
\text { Estimate }\end{array}$ & t-value & $\begin{array}{l}\text { Standardized } \\
\text { Solution }\end{array}$ \\
\hline$\lambda_{1}$ & $1.000^{*}$ & N/A & .879 \\
\hline$\lambda_{2}$ & $1.000^{*}$ & N/A & .890 \\
\hline$\lambda_{3}$ & $1.000 *$ & N/A & .666 \\
\hline$\lambda_{4}$ & .801 & 4.25 & .533 \\
\hline$\lambda_{5}$ & 1.145 & 5.15 & .762 \\
\hline$\lambda_{6}$ & $1.000^{*}$ & N/A & .513 \\
\hline$\lambda_{7}$ & 1.224 & 3.50 & .627 \\
\hline$\lambda_{8}$ & .895 & 3.03 & .459 \\
\hline$\lambda_{g}$ & $1.000^{*}$ & N/A & .815 \\
\hline$\lambda_{10}$ & .860 & 7.78 & .701 \\
\hline$\lambda_{11}$ & 1.173 & 11.70 & .956 \\
\hline$\lambda_{12}$ & .845 & 7.59 & .688 \\
\hline$\lambda_{13}$ & .998 & 9.54 & .813 \\
\hline$\delta_{1}$ & $.228^{*}$ & N/A & \\
\hline $\boldsymbol{\delta}_{2}$ & $.208^{*}$ & N/A & \\
\hline$\varepsilon_{1}$ & .557 & 5.19 & \\
\hline $\boldsymbol{\varepsilon}_{2}$ & .716 & 6.18 & \\
\hline$\varepsilon_{3}$ & .419 & 3.89 & \\
\hline $\boldsymbol{\varepsilon}$ & .737 & 5.82 & \\
\hline Es & .606 & 4.68 & \\
\hline$\varepsilon_{6}$ & .789 & 6.15 & \\
\hline$\varepsilon_{7}$ & .336 & 6.01 & \\
\hline E8 & .509 & 6.61 & \\
\hline E9 & .086 & 2.31 & \\
\hline$E_{10}$ & .526 & 6.64 & \\
\hline$\varepsilon_{11}$ & .339 & 6.03 & \\
\hline$\gamma_{1}$ & .346 & 2.63 & .456 \\
\hline$n$ & -.087 & -.72 & -.117 \\
\hline $\boldsymbol{\beta}_{1}$ & .609 & 3.46 & .791 \\
\hline$\beta_{2}$ & .061 & .12 & .039 \\
\hline$\beta_{3}$ & -.103 & -.27 & -.084 \\
\hline$\phi$ & .422 & 3.89 & .540 \\
\hline
\end{tabular}

* Constrained parameter.

N/A Not applicable.

beta-1 is 609 and statistically significant. Increased competitive intensity is associated with increased emphasis on nonprice marketing strategy. This implies that business executives are active participants in the business game. As the competitive vice tightens, they strive to take steps which will presumably alleviate the pressures of competition.

Hypothesis-five is not supported; while beta-2 is positive, it is not statistically significant. Increased emphasis on nonprice marketing strategy is therefore unrelated to business performance. This outcome is very surprising and will be discussed in detail in the section below.

Finally it should be noted that beta-3 is negative as expected, however, it is not statistically significant. Increased competitive intensity is unrelated to business performance. This result is also not intuitively appealing and it will be discussed shortly.

\section{DISCUSSION}

What has this initial assessment of the SCP paradigm revealed? It has provided evidence which suggests that (a) executives believe that a turbulent macroenvironment (mainly as represented in resource constraints) influences competi- tive intensity and that (b) organizations will respond to increased competitive pressure with more emphasis on nonprice marketing strategies. Thus, as expected, structural elements in the external environment are instrumental in affecting strategy. However, somewhat more problematic, we find no direct relationship between the level of competitive intensity and expected business performance. Moreover, we find that executives project no linkage between the increased usage of nonprice marketing strategies and long-run business performance. Does this suggest that executives believe their nonprice marketing strategies in response to competitive conditions are futile? Not at all. First, the fact that there is no relationship between strategy and performance is not to say that the relationship between strategy and performance is negative. It may be that reliance upon particular strategies in time of macroenvironmental turbulence is exactly what prevents the negative relationship from occuring. Also, increased nonprice strategies are precisely what we would expect to find in intensely competitive markets. Increases in advertising or new product introductions by one competitor will garner a similar reaction from other competitors. In this manner, the stakes of the game increase, but the probabilities of success do not. Hence, the lack of a stronger relationship between conduct and performance is not altogether surprising. As Aaker (1984) and others have observed, tactical efforts to hold on to gains in market share are difficult. In general, the greater the extent to which the competition recognizes growth opportunities, the more difficult it is for the individual firm to grow and be profitable (Wensley 1982). In addition, it should be granted that nonprice strategies may influence short-term performance but in the long run they may be a minor factor.

Many executives may believe that the multitude of random shocks from the external environment primarily determines the fortunes and doom of U.S. business over the long pull. The best thought-out plans and strategies may be destroyed by supposedly random events. From an organizational psychology standpoint, this finding may be consistent with some of the theories of Rotter $(1966 ; 1975)$ who argues that there are many managers who perceive that events are externally controlled. In other words, they believe most outcomes are the result of external causes rather than their own actions. Experience with failures of the past may have reinforced in managers' minds that hard work and planning may or may not pay off. Or it may suggest that many outcomes in business are stochastic, that is, they are the result of "business luck." We believe this business luck thesis is worth further investigation because it is especially intriguing.

Many strategic decisions may be nothing more than informed speculation. This speculation may result in the correct guess. As Alchian stated in the Journal of Political Economy in 1950, "Even in a world of stupid men there would still be profits. Also, the greater the uncertainties of the world, the greater is the possibility that profits would go to venturesome and lucky rather than to logical, careful, fact-gathering individuals." (p. 213). Thus, the link between reasoned action and profits may be nil. Furthermore, the observance of successful firms year after year is no proof that reasoned action led to success; the repeated success could be due to luck! As support for this position consider the chance model of Borel, 
the renowned French mathematician (as reported by Alchian 1950, p. 215).

Suppose two million Parisians were paired off and set to tossing coins in a game of matching. Each pair plays until the winner on the first toss is again brought to equality with the other player. Assuming one toss per second for each eighthour day, at the end of ten years there would still be, on the average, about a hundred-odd pairs; and if the players assign the game to their heirs, a dozen or so will still be playing at the end of a thousand years! The implications are obvious. Suppose that some business had been operating for one hundred years. Should one rule out luck and chance as the essence of the factors producing the long-term survival of the enterprise? No inference whatever can be drawn until the number of original participants is known; and even then one must know the size, risk, and frequency of each commitment. One can see from the Borel illustration the danger in concluding that there are too many firms with long lives in the real world to admit an important role to chance. On the contrary, one might insist that there are actually too few!

What we are essentially asking, is what does organizational success or firm survival signal? According to Monieson and Shapiro (1980) survival of an institution to the functionalist ' is considered 'per se' evidence that institution is performing a service which is useful and possibly even essential to society" (p. 9). On the other hand, these same authors argue a more contemporary postulate is that "evolution is a matter of blind chance with survival depending on genetic fitness rather than any recognized degree of usefulness to a larger entity" (p. 9). Thus, according to Monieson and Shapiro (1980) survival is due to being genetically fit by serving society. The important point to note however, is that neither of these explanations supercede a "luck" hypothesis. If "serving" and being "genetically fit" are stochastic versus deterministic processes then luck can explain both causes. That is, those that survived served society but serving may have been stochastic; furthermore those that were genetically fit survived but being blessed with genetic fitness may have been stochastic. Any expost facto differentiating characteristics between survivors and nonsurvivors does not rule out stochastic processes. For example, surviving firms could be shown to have superior managers to nonsurviving firms but this does not suggest that surviving was determininistic. The allocation of managers to firms may have been stochastic and thus survival was stochastic.

The largest stream of research that would support a link between marketing strategy and business performance is the PIMS research project (Buzzel, Gale, and Sultan 1975; Buzzel and Weirsema 1981). In this series of research, several actions or strategies are shown to relate to ROI. Perhaps one of the strongest and most talked about links to be discovered was between market share and ROI. Supposedly high market share leads to high ROI although recent writings such as
Jacobson and Aaker (1985) have gone far to diffuse this theory. Thus, it is possible that this link could also be due to business luck or chance. An example by Mancke (1974) can illuminate this possibility. A consortium of oil companies of which Phillips Petroleum Company was managing partner announced discovery of a seven-billion barrel oil field in the North Sea in 1970. In the following years because of this largely chance discovery, Phillips market share and profits rose. In short, the positive correlation between market share and profits was due to luck. Is this an isolated example? Perhaps not. The simultaneous rise in profits and market share at General Motors beginning in the early 1920 s was largely due to Henry Ford refusing to deviate from his historical, production oriented, winning strategy. If G.M. had not been so lucky as to have a competitor that refused to innovate, the market share and profits at G.M. would not have been so strongly correlated. The origin of Levi-Strauss company presents a similar example drawn from the annals of business history. When Strauss left for the west coast of the U.S. during the 1849 gold rush, he did so with the intention of selling denim tents. However, what he found out was that the miners needed durable pants rather than tents. Thus, chance and necessity became the parents of an American clothing tradition as well as what is today the world's largest purveyor of jeans.

In yet another line of reasoning the link between strategy (or conduct) and performance is also attributed to chance. Lippman and Rumelt (1982) believe that the world is ambiguous and as a result organizations have trouble identifying the factors that cause business success. The only way a firm can discover its actual demand or cost function for a new technology or new strategy is to make a nonrecoverable investment. Because of this ambiguity, successful strategies are not efficiently imitated and the factors of production are not highly mobile (that is, because few others know the true value of these factors). Thus winning profit strategies cannot be imitated and strategy and performance end up being unrelated. They suggest that "... all firms act to maximize net expected wealth and some are just 'luckier' than others." As it happens the history of business is replete with examples of nonprice strategies that did not help business but actually harmed business performance. This is not to deny the successful implementation of countless profitable strategies. The data does not suggest that nonprice strategy harms business performance. If harming business was the dominant result of nonprice strategy, such behavior would eventually be extinguished by firms because engaging in the behavior would make them more vulnerable to extinction. Consequently, we are left with the uneasy notion that the relationship between strategy and performance is unclear. Recent reviews of the empirical literature related to the issue end up articulating a similar position (Shrader, Taylor, and Dalton 1984).

If the preceding is a correct assessment - and it may or may not be-what are the implications? From a public policy perspective, it could be argued that if organizational conduct doesn't influence long-run business performance then attempting to regulate competition by altering the structure of an industry may be fruitless. Barriers to entry such as heavy investments in advertising and other forms of nonprice marketing strategy may have little influence on ultimate 
success. Thus, using legislation to change industry structure or reduce barriers will not eliminate the formation of large and very powerful business firms. The bottom line, although disquieting to some public policymakers, is that in the sweepstakes for business fortunes some firms will win big and others will struggle with a mediocre existence regardless of industry structure and business conduct.

From a managerial perspective, this research suggests that firms be prepared to respond aggressively to random shocks, in the environment. If long-nun business performance is not greatly influenced by nonprice marketing strategy and if it is caused by random shocks, then firms must monitor these shocks and translate them into opportunities. Importantly, these shocks cannot be readily predicted. Thus a firm must have an agile scanning mechanism in conjunction with a flexible marketing organization.

Before any of these implications are strongly embraced much more refinement of the SCP paradigm is necessary. We only tapped a small set of environmental forces and types of conduct. The door is ajar for more research using this paradigm along with the futures research method that was utilized in this article.

\section{NOTES}

1. In some strict interpretations of the industrial organization/market structure literature, structure refers to market structure and not the structural aspects of other external environments; conduct includes behavior other than marketing decisions, for example, it includes research and development and legal actions; and performance refers to more than organizational performance but to macro systemic performance measures such as equity, full employment, and production and allocative efficiency (see Carman 1977). However, there are other interpretations which urge both a more flexible and comprehensive interpretation of these variables (Preston 1977). This article follows this latter approach.

2. The definitions we will offer have been influenced by many individuals, but most notably Buzzell (1972), Preston (1977), Serpkenci (1984), Stem and Grabner (1970), and Vernon (1972).

3. For an English translation of this manuscript see Schumacher (1984).

4. Presented in a lecture delivered in Stockholm, Sweden in December 1977 when he received the Nobel Prize in Chemistry.

\section{REFERENCES}

Aaker, David A. 1984. Strategic Marketing Management. New York: John Wiley and Sons.

Adams, Richard Newbold. 1978. "Man, Energy, and Anthropology: I Can Feel the Heat, But Where's the Light?" American Anthropologist. Vol. 80, pp. 297-309.

Adel-Khalik, A.R. 1974. "The Entropy Law, Accounting Data, and Relevance to Decision-Making." The Accounting Review 49 (April): 271-283.

Alchian, Armen A. 1950. "Uncertainty, Evolution, and Economic Theory." Journal of Political Economy (June): 211-221.

Atwater, Thomas V. 1979. " 'Lost' or Neglected Components of a General Equilibrium Theory of Marketing." In O.C. Ferrell, Stephen W. Brown, and Charles W. Lamb, Jr. (eds.). Conceptual and Theoretical Develop- ments in Marketing. Chicago: American Marketing Association, pp. 184 196.

Ayers, Roben and Indira Nair. 1984. "Thermodynamics and Economics." Physics Today (November 1984: 62-71.

Biggadike, Ralph E. 1981. "The Contributions of Marketing to Strategic Management." Academy of Management Journal. Vol. 6, No. 4, p. 681.

Boulding, Kenneth E. 1956. "General Systems Theory-The Skeleton of Science." Management Science 2 (April): 197-208.

-1981. Evolutionary Economics. Beverly Hills, Califomia: Sage Publications.

Brent, Sandor B. 1978. "Prigogine's Model for Self-Organization in Nonequilibrium Systems: Its Relevance for Developmental Psychology." Human Development. Vol. 21, pp. 374-387.

Buzzell, Robert, D. 1972. "Marketing and Economic Performance: Meaning and Measurement." Marketing Science Inst itute (August).

-, Bradley T. Gale, and Ralph G.M. Sultan. 1975. "Market Share-A Key to Profitability." Haruard Business Review 53 (January-February): 97-106.

and Frederick D. Wiersema. 1981. "Modeling Changes in Market Share: A Cross-sectional Analysis." Strategic Management Journal 2 (January-March): 27-42.

Carman, James M. 1977. "Theories to Describe Some Competitive Conditions in Which the Firm Operates." In F.M. Nicosia and Y. Wind (eds.). Behavioral Models for Marketing Analysis. Hinsdale, IL: Dryden Press, pp. $147-162$.

1980. "Paradigms for Marketing Theory." Research in Marketing Vol. 3, pp. 1-36.

Caves, Richard. 1964. American Industry: Structure, Conduct, Performance. Englewood Cliffs, New Jersey: Prentice-Hall, Inc.

Chamberlain, Edward H. 1958. The Theory of Monopolistic Competition. Seventh edition. Cambridge: Harvard University Press.

Cook, Norman D. 1980. Stability and Flexibility: An Artalysis of Natural Systems. Oxford: Pergammon Press.

Cozzolino,J.M. and J.J.Zahner. 1973. "The Maximum-Entropy Distribution of the Future Market Price of a Stock." Operations Research 21 (Novernber-December): 1200-1211.

Day, George S. 1984. Strategic Market Planning: The Pursuit of Competitive Advantage. New York: West Publishing Co.

Desaubliaux. 1919. "The Biological Origins of the Administrative Function." Monthly Reports of the Meetings of the Society of the Mineral Industry. Saint-Etienne, At the Society's Efies, Parisian District. Translation obtained from B.G. Schumacher, Norman, Oklahoma.

Dowling, Grahame R. 1983. "The Application of General Systems Theory to an Analysis of Marketing Systems." Journal of Macromarketing (Fall): 22-32.

Edmundo, S.W. 1982. "The Role of Futures Studies in Business Strategic Planning." Journal of Business Strategy (February): 40-46.

Emery, F.E. and E.L. Trist. 1965. "The Causal Texture of Organizational Enviromments." Human Relations. Vol. 18, pp. 21-32.

Enis, Ben M. 1982. "Toward a Taxonomy of Marketing Terms." In Ronald F. Bush and Shelby D. Hunt (eds.). Marketing Theory: Philosophy of Science Prespectives. Chicago: American Marketing Association, pp. 26-33.

Fawles, Jib (ed.). 1978. The Handbook of Futures Research. Westpon, Conn.: Greenwood Press.

Glasser, S. and M.I. Halliday. 1980. "Organizations as Systems." Human Relations. Vol. 33, pp. 917-928.

Henderson, Bruce D. 1983. "The Anatomy of Competition." Journal of Marketing (Spring): 7-11.

Hemiter, Jerome. 1973. "An Entropy Model of Brand Purchase Behavior." Journal of Marketing Research 10 (November): 361-375.

Hofer, C.W. and D. Schendel. 1978. Strategy Formulation: Analytical Concepts. New York: West Publishing Co.

Horowitz, A.R. and I. Horowitz. 1968. "Entropy, Markov Processes, and Competition in the Brewing Industry." Journal of Industrial Economics 16, pp. 196-211.

Hunt, Shelby D. and Lawrence B. Chonko. 1984. "Marketing and Machiavellianism." Journol of Marketing 48 (Summer): 30-42.

Hutt, M.A., R.D. Ireland and G. Stader. 1982. "Functional Importance and Company Performance: Moderating Effects of Grand Strategy and Industry Type." Strategic Management Journal. Vol. 3. pp. 315-330.

Jacobson, Robert and David A. Aaker. 1985. "Is Market Share All That It's Cracked Up to Be?" Journal of Marketing 49 (Fall): 11-22. 
Toskog, K.G. and Dag Sortom. 1983. LISREL User's Guide. Chicago: intemational Educational Services.

7. ingun, Norman. 1981. "Marketing and the Entropy Process: A New World View." In Kenneth Bemhard et al. (eds.). The Changing Marketing Environment: New Theories and Applications. Chicago: Americen Marketing Association, pp. 434-437.

Mizer, William and Eugene J. Kelley. 1962. "A Systems Perspective of Marketing Activity." In William Lazer and Eugene J. Kelley (eds.). Managerial Marketing Perspectives and Viewpoints. Revised edition. Homewood, IL: Richard D. Irwin, pp. 191-198.

Uimeman, R.E. and H.E. Klein. 1985. "Using Scenarios in Strategic Decisionmaking." Business Horizons (January-February): 64-74.

Lippman, S.A. and R.P. Rumelt. 1982. "Uncertain Imitability: An Analysis of Interfirm Differences in Efficiency Under Competition." The Bell Journal of Economics. Vol. 13, pp. 418-438.

Lockley, Lawrence C. 1964. "An Approach to Marketing Theory." In Reevis Cox, Wrol Alderson, and Stanly Shapiro (eds.). Theory in Marketing. Homewood, IL: Richard D. Irwin 1964, pp. 37-50.

Lusch, Robert F. and Gene R. Laczniak. 1979. "Does Futures Research Have a Role In Marketing Theory?" In O.C. Ferrell, Stephen W. Brown, and Charles W. Lamb, Jr. Conceptual and Theoretical Developments In Marketing. Chicago: American Marketing Association, pp. 246-257.

—_, and Jon G. Udell. 1976. "The Future of Marketing Strategy." Business Horizons 19 (December): 65-74.

Mancke, Richard B. 1974. "Causes Of Interfirm Profitability Differences: New Interpretation Of The Evidence." The Quarlerly Journal Of Economics (May): 181-193.

Maruyama, Magorah. 1978. "Prigogine's Epistemology and lts Implications for The Social Sciences." Current Anthropology (June 1978): 453-455.

Metcalfe, J.L. 1974. "Systems Models, Economic Models and the Causal Texture of Organizational Environments: An Approach to Macro-Organization Theory." Human Relations. Vol. 27, No. 7, pp. 639-663.

Monieson, David D. and Stanley J. Shapiro. 1980. "Biological and Evolutionary Dimensions of Aldersonian Thought: What He Borrowed Then and What He Might Have Borrowed." In Charles W. Lamb, Jr. and Patrick M. Dunne (eds.). Theoretical Developments in Marketing. Chicago: American Marketing Association, pp. 7-12.

Monieson, David D. 1981. "Marketing and the Theory of Dissipative Suructures." In Kemeth Bernherdt et al. (eds.). The Changing Marketing Environment: New Theories and Applications. Chicago: American Markeling Association, pp. 441-444.

Montgomery, D.B. and Charles B. Weinberg. 1979. "Toward Strategic Intelligence Systems." Journal of Marketing 43 (Fall): 41-52.

Nicolis, Gregoire and Ilya Prigogine. 1977. Self-organization in Nonequilibrium Systems: From Dissipative Struct ures to Order Through Fluctuations. New York: John Wiley.

Nunnally, Jum C. 1967. Psychometric Theory. New York: McGraw-Hill Book Co.

Pearce, J.A., II and R.B. Robinson. 1983. " Environmental Forecasting: Key to Strategic Management." Business (July-September): 3-12.

Pfeffer, J. and G.R. Salancik. 1978. The External Control of Organizations. New York: Harper and Row Publishing.

Ponter, Michael E 1980. Compelitive Strategy. New York: Free Press, p. 4

Preston, Lee E. 1977. "Strategy-Structure-Performance: A Framework for Organization/Environment Analysis." In H.B. Thorelli (ed.). Strategy + Structure $=$ Performance. Bloomington, Indiana: Indiana University Press, pp. 30-49.

Prigogine, Ilya. 1978. "Time, Structure, and Fluauations." Science 201 (Seprember): 777-785.

,Gregoire Nicolis, and Agnes Babloyantz. 1972a. "Thermodynamics of Evolution." Physics Taday (November): 23-28.

1972b. "Themodynamics of Evolution." Physics Taday (December): $38-44$.

and Isabelle Stengers. 1984. Order Ous of Chaos. New York: Bantam Books.

Ramanujum, V. and N. Venkatramon. 1984. "An Inventory and Critique of Strategy Research Using the PIMS Data Base." Academy of Management Review. Vol. 9, pp. 138-151.

Reidenbach, R. Eric and Terence A. Oliva. 1982. "A Preenalytic Approach to Modeling Macromarketing Behavior." In Ronald F. Bush and Shelby D. Hunt (ods.). Marketing Theory: Philosophy of Science Perspectives. Chicago: American Marketing Association, pp. 242-245.
1983. "Toward a Theory of the Macro Systemic Effects of the Marketing Function." Journal of Macromarketing (Fall): 33-40.

Robey, Daniel. 1982. Designing Organizations: A Macro Perspective. Homewood, IL: Richard D. Irwin.

Robicheaux, Robert A. 1976. "How Important is Pricing in Competitive Strategy?" In Henry W. Nash and Donald P. Robin (eds.). Proceedings: Southern Marketing Association, pp. 55-57.

Rotter, J. 1966. "General Expectancies for Internal versus Extemal Control of Reinforcements." Psychological Monographs. Vol. 80 (1, Whole No. 609).

1975. "Some Problems and Misconceptions Related to the Construct of Internal versus Extemal Control of Reinforcement." Journal of Consulling and Clinical Psychology. Vol. 43. pp. 56-67.

Schumacher, B.G. 1984. On The Origin and Nalure of Management. Norman, Otlahoma: Eugnosis.

Serpkenci, Ray. 1984. An Investigation Into the Determinants of Retail Store Performance. Ph.D. Dissertation, The University of Oklahoma.

Shaw, A.W. 1912. "Some Problems In Market Distribution." Quarterly Journal of Economics. Vol. XXXX (August).

Scherer, F.M. 1980. Industrial Market Struclure and Economic Performance. Chicago: Rand McNally College Publishing Company, second edition.

Shrader, C.B., L. Taylor, and D.R. Dalton. 1984. "Strategic Planning and Organizational Performance: A Critical Appraisal." Journal of Management. Vol. 10, pp. 149-171.

Stem, Louis W. and John W. Grabner. 1970. Compet tition in the Marketplace. Glenview, IL: Scout Foresman and Co.

Terreberry, S. 1968. "The Evolution of Organizational Environments." Vol. 12, Administrative Science Quarterly, pp, 396-419.

Udell, Jon G. 1972. Successful Marketing Strategies. Madison, Wisconsin: Mimir Publishing, p. 33.

Varela, F.G., H.R. Maturana, and R. Uribe. 1974. "Autopoiesis: The Org anization of Living Systems, Its Characterization and a Model." BioSystems. Vol. 5, pp. 187-196.

Vemon, John M. 1972. Market Structwre and Industrial Performance: A Review of Statistical Findings. Boston: Allyn and Bacon.

Watson, Goodwin. 1972. "Resistance to Change." In Creating Social Change. G. Zaluman, P. Kotler, and I. Kaufman (eds.). New York: Holt, Rinehart and Winston, pp. 615-617.

Webster, Frederick E. 1981. "Top Management's Concerns About Market ing: Issues for the 1980's." Journal of Marketing 45 (Summer): 9-16.

Weiss, Leonard W. 1971. "Quantitative Studies of Industrial Organization." In Michael D'Yntriligator (ed.). Frontiers of Quantitative Economics. Amsterdam: North Holland, pp. 363-411.

Wensley, Robin. 1982. "PIMS and BIG: New Horizon or False Dawn?" Stralegic Management Journal. Vol. 3, pp. 147-158.

Wilson, David T. and Morry Ghingold. 1980. "Building Theory From Practice: A Theory-In-Use Approach." In Charles W. Lamb, Jr. and Palrick M. Dunne (eds.). Theoretical Developments in Marketing. Chicago: American Marketing Association, pp. 236-239.

Wind, Yoram and T.S. Robertson. 1983. "Marketing Strategy: New Directions for Theory and Research." Journal of Marketing 47 (Spring): 12-25.

Zaltman, Gerald, Karen LeMasters, and Michael P. Heffring. 1982. Theory Construction in Marketing: Some Thoughts on Thinting. New York: John Wiley and Sons.

Zimmerman, Erich. 1951. World Resources and Industries. Second edition. New York: Harper \& Row.

\section{ABOUT THE AUTHORS}

ROBERT F. LUSCH received his Ph.D. in Business Administration at the University of Wisconsin, Madison in 1975 and is currently Dean of the College of Business Administration at the University of Oklahoma.

GENE R. LACZNIAK received his Ph.D. in Business Administration at the University of Wisconsin, Madison in 1976. $\mathrm{He}$ is currently Professor of Business and Chair, Marketing at Marquette University (Milwaukee, WI). 